\title{
MODEL BIOMEDYCZNY W PSYCHOPATOLOGII. KRYTYCZNY SZKIC HISTORYCZNY, WSPÓŁCZESNY KONTEKST I PROBLEMY ETYCZNE
}

\author{
- Radosław Stupak -
}

\begin{abstract}
Abstrakt: Artykuł prezentuje krytyczny szkic historyczny i charakterystykę biomedycznego modelu psychopatologii, koncentrując się na drugiej połowie XX w. Wskazuje i opisuje także kluczowe problemy związane z jego dominacją we współczesnej praktyce klinicznej i badawczej. Problemy te dotyczą, m.in., trafności i rzetelności diagnoz psychiatrycznych, metodologii badań, skuteczności leczenia, czy też wpływów koncernów farmaceutycznych na działalność naukową i terapeutyczną. Poważne konceptualne problemy całego modelu stawiają pod znakiem zapytania fundamenty współczesnej psychiatrii oraz opartą na nich wiedzę. Pomimo wielu lat hojnie finansowanych badań odwołujących się do biomedycznego paradygmatu, nie udało się stworzyć przekonujących biologicznych wyjaśnień zaburzeń psychicznych ani zidentyfikować mechanizmów odpowiadających za ich powstawanie. Uzasadnione wątpliwości istnieją także w odniesieniu do leków przeciwpsychotycznych i antydepresyjnych - pomimo ich coraz szerszego stosowania, przybywa ludzi przewlekle chorych. Rodzi to poważne dylematy etyczne i uzasadnione pytania o nadmierną medykalizację kwestii wiązanych ze zdrowiem psychicznym. Konieczna wydaje się reforma dominującego modelu i wzrost nakładów na badania i praktykę uwzględniającą czynniki psychologiczne, społeczne i kulturowe.
\end{abstract}

Słowa kluczowe: model biomedyczny, bioetyka, historia psychiatrii, filozofia psychiatrii, psychopatologia, medykalizacja, farmakoterapia, psychoterapia, schizofrenia, depresja.

Published online: 15 May 2020

Jakkolwiek dominujący obecnie paradygmat nazywa się zazwyczaj oficjalnie biopsychospołecznym, to niektórzy autorzy posuwają się nawet do określania rzeczywistych praktyk modelem bio-bio-bio ${ }^{1}$. Na faktyczny prymat biomedycznego, czy też przyrodoznawczego modelu psychopatologii zwraca się uwagę także w Polsce $^{2}$. W powszechnie obowiązującej narracji coraz lepsze rozumienie biologicznych podstaw zaburzeń psychicznych prowadzi do skuteczniejszych i bezpieczniejszych terapii. Równocześnie coraz głośniej mówi się wręcz o kryzysie psychiatrii ${ }^{3}$. Celem niniejszego artykułu jest naszkicowanie, z krytycznej

\footnotetext{
Radosław Stupak Instytut Filozofii UJ Grodzka 52 31-044 Kraków e-mail: radek.stupak@doctoral.uj.edu.pl

${ }^{1}$ Read, Bentall, Fosse (2009).

2 de Barbaro (2014); Waszkiewicz, Nizio (2014).

${ }^{3}$ Pużyński (2014).
} 
perspektywy, historii powstania biomedycznego modelu psychopatologii, jego krótka charakterystyka oraz wskazanie kluczowych teoretycznych i etycznych problemów związanych z nim we współczesnej praktyce klinicznej i badawczej.

\section{Wprowadzenie}

Już w 1858 roku artykuł wstępny „Journal of Mental Science” głosił: „Szaleństwo jest wyłącznie chorobą mózgu. Lekarz staje się odpowiedzialnym opiekunem szaleńca i musi na zawsze nim pozostać" 4 . Podobnie w Niemczech, Wilhelm Griesinger, ojciec i popularyzator koncepcji „Somatiker” oraz autor jednego z najbardziej wpływowych podręczników psychiatrii, na którym wychowały się generacje dziewiętnastowiecznych lekarzy, uważał, że "choroby psychiczne to choroby mózgu" ${ }^{5}$. Jednak jeszcze na początku XX w. w Europie Zachodniej i Stanach Zjednoczonych psychiatria uważana była za specjalizację drugiej kategorii, przyciągającą najmniej zdolnych adeptów Eskulapa i lekarzy z odległych kolonii 6 . Zaś w 1914 r. prezes ówczesnego Royal College of Psychiatry lamentował publicznie nad statusem psychiatrii jako „kopciuszka medycyny” i niskimi zarobkami psychiatrów ${ }^{7}$. Następne 100 lat to, zakończone niebywałym sukcesem, na który złożyło się wiele różnorakich czynników i sprzyjających okoliczności, próby zmiany tego stanu rzeczy. Doprowadziły one m.in. do dominacji we współczesnej praktyce badawczej i klinicznej biomedycznego modelu psychopatologii.

Kształt współczesnych koncepcji psychopatologicznych nierozerwalnie związany jest z charakterem i ewolucją XX-wiecznej psychiatrii. Jej historia przedstawiana jest zazwyczaj dwojako: psychiatria od zawsze była zainteresowana potwierdzeniem swojego statusu jako dziedziny medycyny i, co za tym idzie, nieustannie koncentrowała się na poszukiwaniu biologicznych wyjaśnień i takich też terapii zaburzeń psychicznych, a psychoanaliza, czy terapia moralna, były tylko przejściową anomalią ${ }^{8}$, lub też, przeciwnie, XX-wieczna psychiatria opisywana jest jako zdominowana przez tego rodzaju alternatywne podejścia, odwodzące ją od właściwego i jedynie słusznego biologicznego kierunku, na który triumfalnie z końcem wieku powróciła ${ }^{9}$. Niezależnie od przyjętej optyki, dwa wydarzenia wydają się kluczowe, jeśli chodzi o genezę obecnego kształtu modelu biomedycznego zaburzeń psychicznych, mianowicie: odkrycie psychotropowego działania chlorpromazyny w 1952 r. oraz publikacja trzeciej edycji Diagnostic and Statistical Manual of Mental Disorders (DSM-III) w 1980 r. ${ }^{10}$. Do tych dwóch wydarzeń Healy ${ }^{11}$ dodaje jeszcze rewolucję obyczajową roku 1968, której częściowo antypsychiatryczny

\footnotetext{
${ }^{4}$ Rogers, Pilgrim (2011): 46.

${ }^{5}$ Ellenberger (1970): 241.

${ }^{6}$ Moncrieff (2008).

7 Bond (1914).

8 Por. Scull (1994).

9 Por. Shorter (2005).

${ }^{10}$ Zarówno historia popularyzacji chlorpromazyny (a także, później, szczególnie fluoksetyny oraz tzw. atypowych neuroleptyków), jak i szerszy naukowy i społeczny kontekst powstania DSM-III (oraz kolejnych jego wersji) i zawartych w klasyfikacji poszczególnych diagnoz zasługują na odrębny dogłębny opis i analizę, nie ma tutaj jednak na to miejsca.

${ }^{11}$ Healy (2002).
} 
(a generalnie anty-establishmentowy) charakter miał z jednej strony podważyć narrację dotycząca takich figur jak Kraepelin, Pinel, czy Freud i przekonstruować ich postrzeganie z postaci pozytywnych-wyzwolicieli w symbole społecznej opresji, a z drugiej, jeszcze mocniej uświadomił psychiatrom konieczność oparcia swojego autorytetu na biologicznym, medycznym, naukowym fundamencie, mniej, wydawałoby się, podatnym na społeczne i kulturowe zawirowania. W kształtowaniu się modelu biomedycznego nie można także przecenić roli koncernów farmaceutycznych ${ }^{12}$.

\section{Podstawowe założenia}

W 1975 r. Arnold Ludwig w komentarzu opublikowanym w "Journal of the American Medical Association", symptomatycznie zatytułowanym Psychiatra jako lekarz, wyłożył w zasadzie podstawowe założenia modelu biomedycznego, który, okazało się, miał obowiązywać przez następne półwiecze i zdominować myślenie o psychopatologii. Co ciekawe, pisał wtedy jeszcze, że podstawową różnicą między medycznym a niemedycznymi modelami zaburzeń nie jest naukowość tego pierwszego (później argument o naukowości miał stać się jednym z głównych atutów modelu biomedycznego), lecz założenie, że wystarczające odchylenie od normy oznacza chorobę. Choroba ta wynika ze znanych lub nieznanych przyczyn naturalnych, a wyeliminowanie tych przyczyn prowadzić będzie do wyleczenia lub poprawy stanu pacjenta. Choć Ludwigis przyznaje, że diagnozy psychiatryczne mają raczej charakter hipotez i gorszą rzetelność od diagnoz stosowanych w innych dziedzinach medycyny, to przy tym jednak nadal mogą być uznawane za jakościowo tożsame, jeśli utrzymane zostanie założenie o biologicznych przyczynach problemów, w przeciwieństwie do przyczyn psychologicznych, interpersonalnych, czy społecznych. Choroby psychiczne miałyby być definiowane jako ciężkie poznawczo-afektywne zaburzenia zachowania spowodowane biochemicznymi lub neurofizjologicznymi dysfunkcjami mózgu. Co może jeszcze ciekawsze, według autora wykluczałoby to $\mathrm{z}$ obszaru zainteresowania psychiatrii np. dysfunkcje związane z adaptacją społeczną, zaburzeniami osobowości, czy nadużywaniem substancji zmieniających świadomość, o których stwierdził, że pojawiają się najprawdopodobniej u ludzi ze "zdrowym” układem nerwowym.

Oczywiście Ludwig nie przewidział, jak wprowadzenie w życie zasad, które sam zaproponował, może posłużyć do medykalizacji coraz szerszej gamy ludzkich zachowań, a w każdym razie do inflacji/namnożenia kategorii diagnostycznych. Kiedy publikował swój tekst obowiązywał jeszcze DSM-II, w którym znaleźć można było 193 diagnozy, w DSM III było ich już 228 (253 w DSM III-R), w DSM IV - 383, a w DSM 5 - 541 ${ }^{14}$. Wbrew temu, co mogłoby się wydawać, diagnozy DSM-III nie powstały na podstawie badań epidemiologicznych czy innych empirycznych danych. Kategorie i kryteria diagnostyczne wymyślano na bieżąco podczas spotkań grup roboczych, a ich ostateczny kształt był efektem kompromisu pomiędzy ekspertami wchodzącymi

\footnotetext{
12 Whitaker (2002).

13 Ludwig (1975).

14 Blashfield, Keeley, Flanagan et al. (2014).
} 
w ich skład ${ }^{15}$. Jednak odejście od psychoanalitycznych wyjaśnień i zmiana języka pozwoliły stworzyć aurę obiektywizmu i naukowości. W tym kontekście kluczowe okazały się także randomizowane kontrolowane badania kliniczne (RCT).

\section{Pierwsze nowoczesne badania kliniczne}

RCT są niezwykle istotnym elementem współczesnego modelu biomedycznego w psychopatologii. Pierwsze badanie z podwójnie ślepą próbą w psychiatrii przeprowadzili w 1939 r. Leonard Dub i Louis Lurie ${ }^{16}$. Wykorzystali oni pacjentów z odmienną diagnozą jako swoje własne grupy kontrolne i wykazali, że benzedryna (amfetamina) jest skuteczna w leczeniu depresji, ale nieskuteczna w leczeniu schizofrenii. Pierwsze badania zgodne z formułą RCT w psychiatrii przeprowadzono w 1952 r., aby sprawdzić doniesienia o skuteczności kortyzonu w leczeniu psychoz. Okazało się, że kortyzon nie poprawia stanu pacjentów ${ }^{17}$. Innym wczesnym zastosowaniem RCT w psychiatrii było badanie z 1954 r., w którym to Hoffer, Osmond i Smythies wykazali, że kwas nikotynowy wpływa pozytywnie na przebieg leczenia pacjentów z diagnozą schizofrenii ${ }^{18}$. Wkrótce opublikowali też wyniki, które wykazywały, że terapia niacyną w połączeniu z chlorpromazyną jest skuteczniejsza od terapii samą chlorpromazyną. Badanie to odbiło się szerokim echem, a Osmonda, twórcę terminu psychodeliki, odwiedzał Aldous Huxley pragnący zgłębić tajniki zmieniających świadomość substancji. Co ważniejsze, badania te pozwoliły stworzyć wiarygodną (ówcześnie) i spójną biologiczną teorię etiologii schizofrenii wraz z, wydawało się skuteczną, biologiczną terapią. Hipoteza transmetylacji uzyskała wsparcie m.in. neuropsychologa i laureta nagrody Nobla Johna Ecclesa. Wszystko to nadało badaniom wystarczający rozgłos, aby utorować drogę innym tego typu poszukiwaniom, a także przygotować opinię publiczną do postrzegania procesów i stanów psychicznych przez pryzmat reakcji chemicznych w mózgu.

Mimo że hipoteza transmetylacji (i jej kolejne wersje) zdominowała na niemal dwie dekady biologiczną psychiatrię, przetarła szlaki dla innych badań oraz pośrednio przyczyniła się do ważnych odkryć (m.in. nagrodzonego Noblem odkrycia mechanizmu wychwytu zwrotnego monoamin), wkrótce znalazła się na półce medycyny alternatywnej i próżno szukać wzmianki o niej w większości współczesnych podręczników psychiatrii i psychologii, czy nawet historii psychiatrii ${ }^{19}$.

\section{Od agencji rządowych do badań prowadzonych przez koncerny}

Early Clinical Drug Evaluation Unit (ECDEU), utworzony w Stanach Zjednoczonych w 1958 r. dzięki hojnym rządowym grantom jako część National Institute of Mental Health (NIMH), miał za zadanie m.in. badać bezpieczeństwo nowych leków i określać odpowiednie ich dawki. Federalne fundusze miały zaś zapewnić badaczom nieza-

\footnotetext{
${ }^{15}$ Davies (2017).

${ }^{16}$ Dub, Lurie (1939).

17 Rees, King (1952).

${ }^{18}$ Hoffer, Osmond, Smythies (1954).

${ }^{19}$ Healy (2002).
} 
leżnośćc ${ }^{20}$. Jednak oddelegowani do tego zadania psychiatrzy szybko zdali sobie sprawę z faktu, że rozwiązać muszą najpierw inny problem, przed którym stała naukowa psychiatria: problem pomiaru. Odpowiedzią okazały się skale/kwestionariusze pomiarowe, opracowano wtedy m.in. stosowaną do dziś Brief Psychiatric Rating Scale. Model oparty o RCT i skale to dziś w zasadzie złoty standard wszelkich badań efektywności terapii, zarówno psychiatrycznych, jak i psychologicznych. Jest on jednak także szeroko współcześnie krytykowany z różnorakich teoretycznych i praktycznych pozycji. Moncrieff ${ }^{21}$ formułuje jeden z ciekawszych zarzutów, argumentując, że stosowanie metodologii RCT w badaniach klinicznych kreuje percepcję leków psychiatrycznych jako substancji działających specyficznie na chorobę, podczas gdy, według niej, należałoby raczej mówić o ich ogólnym oddziaływaniu na świadomość. Zaś to ostanie z kolei może maskować, czy też tłumić, niektóre z objawów określonych zaburzeń. Autorka wręcz porównuje działanie leków psychotropowych do narkotyków. Przywołuje przy tym „klasyczny” podział na leki uspokajające i leki pobudzające, obecny jeszcze w podręczniku psychiatrii z 1944 r. i pokazuje, że przed wprowadzeniem i wypromowaniem chlorpromazyny jako leku przeciwpsychotycznego (a więc oddziałującego na chorobę i jej przyczyny), substancje psychotropowe postrzegane były w psychiatrii nie jako lekarstwa, lecz jako substancje zmieniające świadomość. Jest to o tyle ważne, że jednym z podstawowych założeń modelu biomedycznego w ogóle jest poszukiwanie specyficznych postaci czy form interwencji, które oddziałują na określone patologiczne procesy. Jak dowodzi Moncrieff, nie ma o tym mowy we współczesnej psychiatrii. Healy ${ }^{22} \mathrm{z}$ kolei skupia się na gubieniu w RCT jednostkowej reakcji na lek w uśrednionych wynikach. Ma to według niego szereg negatywnych konsekwencji, zarówno jeśli chodzi o praktykę kliniczną, jak i postęp badawczy. Ponadto, twierdzi Healy, z różnych powodów RCT bardziej nadają się do wykazania, że coś nie działa terapeutycznie w określonej chorobie, niż że działa. RCT nie pozwalają również na wnioski dotyczące mechanizmów działania określonych interwencji - można przy ich pomocy tylko próbować ocenić ich skuteczność. Uzasadnione wątpliwości pojawiają się także w odniesieniu do trafności samych skal oraz różnicy między istotnością statystyczną a klinicznym znaczeniem takiej różnicy ${ }^{23}$.

Wreszcie, w połowie lat siedemdziesiątych, w związku m.in. z kryzysem ekonomicznym i wojną w Wietnamie, z powodu braku funduszy rządowych ECDEU w praktyce zakończył działalność. Utworzono New Clinical Drug Evaluation Unit (NCDEU), ale jego charakter był już zupełnie inny. Teraz to koncerny farmaceutyczne miały wynajmować psychiatrów, którym płaciły za prowadzenie badań klinicznych, a dane opracowywane i opisywane były przez pracowników firm. Psychiatrzy często jedynie firmowali nazwiskiem badania, z którymi niewiele mieli faktycznie wspólnego ${ }^{24}$, zdarzało się nawet, że publikowano sfabrykowane dane z badań nad pacjentami, którzy nie istnieli ${ }^{25}$. Te same pozytywne wyniki publikowano wielokrotnie jako różne artykuły ${ }^{26}$,

\footnotetext{
${ }^{20}$ Bernstein (1970).

${ }^{21}$ Moncrieff (2008).

${ }^{22}$ Healy (2002).

${ }^{23}$ Moncrieff, Kirsch (2015).

${ }^{24}$ Hollister (1998).

${ }^{25}$ Eichenwald, Kolata (1999).

${ }^{26}$ Huston, Moher (1996).
} 
negatywnych zaś nie ogłaszano, co wpływało na wyniki metaanaliz, a źródło finansowania stało się najlepszym predyktorem wyniku prób klinicznych - niezależnie od mechanizmu działania leku - lepsze wyniki raportowały badania sponsorowane przez producenta konkretnej substancji ${ }^{27}$. Nadal, w różnych gałęziach medycyny, badania RCT, których autorzy powiązani są finansowano z przemysłem farmaceutycznym, znacznie częściej wykazują pozytywne rezultaty, niż badania, których autorzy nie mają takich powiązań ${ }^{28}$. Wskazać można jeszcze cały szereg stosowanych z premedytacją manipulacji badawczych, w które zamieszane są także czasopisma naukowe ${ }^{29}$. Niedawno także w „Psychiatrii Polskiej” ukazał się artykuł o korupcji w badaniach psychiatrycznych ${ }^{30}$.

Obowiązujące współcześnie regulacje nakazujące ujawnianie powiązań z przemysłem farmaceutycznym są niewystarczające ${ }^{31}$. Na przykład, trzej autorzy artykułów, które przyczyniły się do 40-krotnego wzrostu w diagnozowaniu choroby afektywnej dwubiegunowej (CHAD) u dzieci (i idącego w ślad za tym wzrostu stosowania neuroleptyków) nie ujawnili, że od koncernów farmaceutycznych otrzymali ponad 4 miliony dolarów w ramach honorarium za konsultacje. Fakt ten wyszedł na jaw w związku $\mathrm{z}$ dochodzeniem prowadzonym $\mathrm{w}$ innej sprawie, ale psychiatrów nie spotkały żadne poważne konsekwencje, a artykułów nie wycofano z czasopism ${ }^{32}$.

Oparcie testowania skuteczności medykamentów i wprowadzania nowych farmaceutyków na rynek o opisane wcześniej standardy, z pominięciem np. długoterminowych badań uwzględniających choćby skale jakości życia, ułatwiły tego rodzaju praktyki. Gotzsche ${ }^{33}$, światowy autorytet w badaniach nad efektem placebo i założyciel Cochrane, twierdzi, że przemysł farmaceutyczny prowadził tego rodzaju badania, ale z powodu niekorzystnych rezultatów, zataił ich wyniki. Ogromne fundusze zainwestowane przez koncerny w bezpośrednią reklamę leków, dozwoloną w USA, sponsorowane artykuły i kampanie medialne, gigantyczne psychiatryczne konferencje i honoraria dla prominentnych psychiatrów pozwoliły także przekonać opinię publiczną o skuteczności i naukowych podstawach farmakoterapii, a także pośrednio wpływać na kształt systemów diagnostycznych ${ }^{34}$. Stawia to pod znakiem zapytania bazę, na której opiera się praktyka kliniczna.

Równolegle, psychologia i psychoterapia uwikłane były w swój własny skandal związany z fałszywymi oskarżeniami opartymi na rzekomych wypartych wspomnieniach wykorzystywania seksualnego w dzieciństwie. Healy ${ }^{35}$ wskazuje, że wielu z terapeutów, których techniki kwestionowano, uważało się przede wszystkim za przedstawicieli terapii kognitywno-behawioralnej, którą uznaje on za swoistą odpowiedź psychologii na rzeczywistość DSM-III i RCT. Terapeuci ci, uwiedzeni ideą specyficzności przyczyny i leczenia, charakterystyczną dla modelu biomedycznego, mieli, według

\footnotetext{
${ }^{27}$ Freemantle, Anderson, Young (2000).

28 Ahn, Woodbridge, Abraham et al. (2017).

29 Smith (2005); Spielmans, Parry (2010); Moncrieff (2016).

30 Amsterdam, Henry, Jureidini (2017).

31 Thacker (2018).

32 Sarcher (2011).

33 Gotzsche (2015).

${ }^{34}$ Whitaker (2002); de Barbaro (2014).

35 Healy (2002).
} 
niego, zbyt łatwo uwierzyć w wykorzystywanie seksualne jako tłumaczący wszystko czynnik. Byłby to także przykład tego, jak model biomedyczny wpływał również na, wydawałoby się, czysto psychologiczne koncepcje psychopatologii.

Podsumowując zatem, model biomedyczny zakłada, że zaburzenia psychiczne spowodowane są biologicznymi nieprawidłowościami, przede wszystkim w mózgu, nie ma istotnej różnicy między fizycznymi i psychicznymi chorobami, a nacisk kładziony jest na poszukiwanie i stosowanie terapii biologicznych. Jest to podejście, najkrócej mówiąc, odwołujące się do oświeceniowych, racjonalistycznych, scjentystycznych i pozytywistycznych ideałów.

W słowach samego Thomasa Insela, byłego dyrektora NIMH: „Wiele chorób wcześniej definiowanych jako "psychiczne” uznaje się obecnie za choroby o przyczynie biologicznej”36, czy też: „[...] zaburzenia psychiczne, to choroby mózgu, ta prosta i głęboka prawda całkowicie zmieniła sposób, w jaki podchodzimy do diagnozy i ostatecznie odmieni sposób, w jaki leczymy” ${ }^{37}$. Ten sam Insel przyznaje wprawdzie, że: „Czego nam brakuje, to zrozumienia podłoża biologicznego tych zaburzeń i tego, co właściwie działa źle" ${ }^{\prime 38}$, zapowiada jednak podczas posiedzenia jednej z komisji Kongresu USA w 2006 r., że psychiatria posiada już wystarczająco rzetelne instrumenty, aby zmienić to $\mathrm{w}$ ciągu 5 lat $^{39}$. Cowen i Browning ${ }^{40} \mathrm{~W}$ artykule w prestiżowym „World Psychiatry” z 2015 r. konkludują, że proste teorie depresji łączące ją z poziomem serotoniny są już absolutnie nie do obrony i wysuwają w związku z tym różne hipotezy próbujące wyjaśnić, na czym właściwie może polegać przeciwdepresyjny efekt inhibitorów wychwytu zwrotnego serotoniny (SSRI), co stanowi raczej przykład na potwierdzenie wcześniejszego wyznania dyrektora NIMH.

\section{Problemy}

Przytoczone powyżej słowa sygnalizują pewną dwoistość narracji dotyczącą statusu psychiatrii oraz koncepcji psychopatologicznych i terapii opartych na modelu biomedycznym. Dwoistość tę doskonale opisuje Deacon ${ }^{41}$ warto więc go tu przytoczyć w dłuższym fragmencie:

Zaburzenia psychiczne to choroby mózgu spowodowane rozregulowaniem neuroprzekaźnictwa, anomaliami genetycznymi i defektami struktur i funkcji mózgu. A jednak, naukowcy nie zidentyfikowali biologicznej przyczyny, ani nawet rzetelnego biomarkera, żadnego zaburzenia psychicznego. Leki psychotropowe przeciwdziałają nierównowadze neuroprzekaźników, która powoduje zaburzenia psychiczne. Jednakże, nie ma wiarygodnych dowodów na to, że zaburzenia psychiczne powodowane sa przez chemiczna nierównowagę, ani na to, że lekarstwa działaja poprzez przywracanie równowagi. Postępy

\footnotetext{
${ }^{36}$ Insel (2010).

37 Insel (2006).

38 Insel (2006b).

39 Insel (2006).

40 Cowen, Browning (2015).

41 Deacon (2013).
} 
neuronauk wprowadziły nas w erę bezpieczniejszych i skuteczniejszych terapii farmakologicznych. Przeciwnie, współczesne leki psychiatryczne nie sa, ogólnie rzecz biorac, bezpieczniejsze od tych odkrytych przez przypadek pót wieku temu. Psychiatria biologiczna uczyniła wielki postęp i przyczyniła się do zmniejszenia kosztów społecznych zaburzeń psychicznych. Jednak zaburzenia psychiczne stały się cięższe i bardziej przewlekłe, a liczba ludzi doprowadzonych do niepetnosprawności z powodu ich objawów w ostatnich dekadach stale rosta. Edukowanie opinii społecznej o zaburzeniach psychicznych, jako medycznych chorobach o podłożu biologicznym, przyczynia się do zmniejszania stygmatyzacji. Mimo rosnacego przekonania o biologicznych przyczynach i akceptacji biologicznych terapii, zjawisko stygmatyzacji nie maleje, a nawet wykazuje tendencje wzrostowe. Zwiększone inwestycje w neuronauki doprowadzą do powstania biologicznych testów i leczniczych terapii farmakologicznych. Przemyst farmaceutyczny dramatycznie obniżyt nakłady na poszukiwanie nowych leków psychiatrycznych, w związku z brakiem obiecujących molekularnych celów i częstą niemożnościa wykazania wyższości nowych substancji nad placebo.

Choć niektóre tezy Deacona uznać można za zbyt radykalne, to jednak ogólnie trudno odmówić im słuszności, wiele z nich jest dobrze udokumentowanych, a pojedyncze przypadki, które mogłyby przeczyć jego twierdzeniom, są raczej wyjątkami potwierdzającymi regułę. Szczególną uwagę warto poświęcić kilku kwestiom.

\section{Problemy diagnostyczne}

Aktualnie stosowane systemy klasyfikacji zaburzeń psychicznych krytykowane są nawet przez kierującego pracami nad DSM-IV Allena Francesa. Charakteryzują się m.in. niską rzetelnością ${ }^{42}$ i nakładaniem się na siebie różnych kategorii diagnostycznych ${ }^{43}$. Diagnozy stawiane na podstawie DSM i ICD nie spełniają właściwie definicyjnych wymagań diagnozy, tj. nie pozwalają na zastosowanie odpowiedniego i specyficznego dla nich leczenia, ani na trafne określenie rokowania ${ }^{44}$. Podstawowym problemem jest jednak fakt, że nie udowodniono jakoby współcześnie identyfikowane jednostki chorobowe faktycznie odsyłały do realnych, oddzielnych zaburzeń psychicznych, o specyficznym mechanizmie. Co więcej, różne diagnozy psychiatryczne mają wspólne podłoże genetyczne ${ }^{45}$, co zdaje się potwierdzać tezę, że nie odpowiadają one rzeczywistym, oddzielnym chorobom - szczególnie, jeśli w zgodzie z modelem biomedycznym akcentować rolę czynników genetycznych (ewentualnie wyzwalanych przez stres). Dodatkowo, nawet $\mathrm{w}$ ramach tych samych kategorii diagnostycznych nie znajduje się u pacjentów podobnych odchyleń od normy w budowie mózgu ${ }^{46}$. Czynniki genetyczne wyjaśniają 3,4\% wariancji zapadalności na schizofrenię według jednego z największych badań na ten

\footnotetext{
${ }^{42}$ Williams, Gibbon, First et al. (1992); Frances (2012).

${ }^{43}$ American Psychiatric Association (1994); Dell'Osso, Pini (2012).

${ }^{44}$ Bentall (2003).

${ }^{45}$ The Brainstorm Consortium (2018).

${ }^{46}$ Wolfers, Doan, Kaufmann et al. (2018).
} 
temat opublikowanego w 2014 r. w "Nature" 47 , a często przywoływane wyniki historycznych badań nad odziedziczalnością zostały zniekształcone ${ }^{48}$. Rodzi to oczywiste i istotne problemy, zarówno na gruncie badań i oddziaływań czysto biologicznych, jak i psychospołecznych, ponieważ łącznie traktuje się pacjentów, którzy faktycznie mogą cierpieć na różne zaburzenia ${ }^{49}$. Jeśli zaś wyniki badań dotyczą źle zdefiniowanych jednostek chorobowych, stawia to pod znakiem zapytania całość zgromadzonej wiedzy dotyczącej skuteczności rozmaitych terapii oraz tłumaczy problemy ze znalezieniem ich biologicznych mechanizmów. Kinderman ${ }^{50}$, były prezes British Psychological Society, posuwa się nawet do określenia aktualnych systemów diagnostycznych jako: „niewłaściwych i nieludzkich, a nawet dziwacznych" (invalid and inhumane and even bizarre). Co ciekawe, o konieczności opracowania nowego podejścia do identyfikacji i klasyfikacji zaburzeń mówią zarówno zwolennicy modelu biomedycznego, np. $\mathrm{NIMH}^{51}$, jak i środowiska kojarzone ze zgoła odmiennym podejściem - kwestii nowych ujęć diagnostycznych poświęcono dwa specjalne wydania "Journal of Humanistic Psychology"52.

\section{Wątpliwości co do leczenia - leki przeciwpsychotyczne}

Szczególnie problematycznym i ważkim problemem jest skuteczność leczenia opartego na biomedycznych koncepcjach psychopatologii. Badania longitudinalne pokazują np. że w okresie od dwóch do dwudziestu lat po pierwszym przyjęciu do szpitala psychiatrycznego, najlepsze wyniki na skalach objawowych i funkcjonowania społecznego mają ci pacjenci ze zdiagnozowanymi zaburzeniami psychotycznymi (schizofrenią lub CHAD), którzy nie przyjmowali lub przestali przyjmować neuroleptyki (najczęściej bez konsultacji lub wbrew zaleceniom lekarza) ${ }^{53}$. Choć dane te można starać się na różny sposób wytłumaczyć, także poprzez odwołanie do różnorakich psychologicznych zasobów i koncepcji, uderzający jest fakt, że wyniki stosujących neuroleptyki osób z diagnozą $\mathrm{CHAD}, \mathrm{w}$ trakcie trwania badania stały się gorsze, niż wyniki osób z diagnozą schizofrenii, które nie przyjmowały leków; innymi słowy, osoby z diagnozą schizofrenii funkcjonowały bez leków lepiej niż osoby z diagnozą CHAD stosujące farmakoterapię. Co więcej, 4 i pół roku od pierwszego epizodu, na pół etatu lub cały etat pracowało 87\% nie biorących leków, w porównaniu do $29 \%$ biorących. Podobne proporcje utrzymywały się przez kolejnych 15 lat $^{54}$. Whitaker ${ }^{55}$ przedstawia przekonujące zestawienie badań i teorii dotyczących neuroleptyków, dowodząc, że nie ma żadnych danych, które wskazywałyby na korzyści płynące z długotrwałego ich stosowania, a można nawet mówić o szkodliwości takiego podejścia - wbrew oficjalnej doktrynie i praktyce psychiatrycznej. Potwierdzają to longitudinalne (siedmioletnie) randomizowane badania, w których

\footnotetext{
47 Schizophrenia Working Group of the Psychiatric Genomics Consortium (2014).

${ }^{48}$ Leo (2017).

${ }^{49}$ Kirkpatrick, Buchanan, Ross et al. (2001); Insel (2013).

${ }^{50}$ Kindermann (2014): 17.

${ }^{51}$ Insel (2013).

${ }^{52}$ Kamens, Robbins, Flanagan (2017).

${ }^{53}$ Harrow, Jobe, Faull (2012).

${ }^{54}$ Harrow, Jobe, Faull et al. (2017).

${ }^{55}$ Whitaker (2016).
} 
pacjenci, którym zmniejszano stopniowo dawki leków (niektórym aż do całkowitego ich odstawienia) osiągali, z upływem czasu, lepsze wyniki niż pacjenci leczeni tradycyjnie ${ }^{56}$. Podobne badania, lecz na większą skalę, prowadzone są aktualnie w Wielkiej Brytanii dzięki funduszom z brytyjskiego National Institute of Health Research ${ }^{57}$. Są to oczywiście póki co pojedyncze badania na relatywnie małych grupach osób, problem polega jednak na tym, że pomimo ponad 50 lat stosowania neuroleptyków brak jest jakichkolwiek longitudinalnych badań, które jednoznacznie nakazywałyby wyciągniecie przeciwnych wniosków, jeśli chodzi o długoterminowe prognozy. Z drugiej strony, terapie oparte na zasadniczo odmiennym rozumieniu psychopatologii i odwołujące się w swej istocie do koncepcji społeczności terapeutycznej, czy też konstrukcjonizmu społecznego i dialogiczności, skoncentrowane raczej na działaniach, które należałoby określić jako psychoterapeutyczne, a przy tym starające się minimalizować wykorzystanie leków psychotropowych, osiągają zdumiewająco korzystne (fiński Open Dialogue ${ }^{58}$ ), lub przynajmniej porównywalne i nieco lepsze $\left(S\right.$ Soteria ${ }^{59}$ ) niż leczenie farmakologiczne, rezultaty. Nie ulega wątpliwości, że nagłe odstawienie leków zwiększa ryzyko wystąpienia epizodu psychotycznego w krótkim okresie, jednak przytoczone wyniki badań zdają się sugerować, że, paradoksalnie, (umiejętne) odstawienie leków długoterminowo prowadzić może do lepszego funkcjonowania pacjentów. Postulat dążenia przynajmniej do minimalizacji stosowanych dawek wydaje się więc jak najbardziej uzasadniony. Wszystko to staje się jeszcze bardziej istotne, jeśli wziąć pod uwagę, że, by wymienić tylko kilka z efektów ubocznych stosowania neuroleptyków, powodują one najprawdopodobniej zaburzenia metaboliczne, otyłość i cukrzycę ${ }^{60}$ oraz prowadzą do zmniejszania się masy mózgu ${ }^{61}$. Tymczasem wskaźniki wyzdrowień (recovery) w schizofrenii są współcześnie ponad dwukrotnie niższe niż w latach trzydziestych ubiegłego wieku' ${ }^{62}$.

\section{Leki antydepresyjne}

W wypadku antydepresantów, głośna metaanaliza Kirscha i in. ${ }^{63}$, wykazuje z kolei, że SSRI, powszechnie stosowane w leczeniu depresji i wielu innych zaburzeń psychicznych, w przypadku lżejszych depresji mają skuteczność porównywalną z placebo i niewiele lepszą od placebo w wypadku depresji ciężkich (ten drugi wynik Kirsch tłumaczy nie tyle efektem działania antydepresantów, co mniejszym efektem placebo u osób z ciężką depresją). Niedawny przegląd badań dotyczący tego zagadnienia pokazuje, że teza ta pozostaje trudna do zignorowania lub podważenia, pomimo że wyniki badań zespołu Kirscha spotkały się z szeroką krytyką ${ }^{64}$. Największe badania dotyczące skuteczności antydepresantów, jakie do tej pory przeprowadzono na świecie, w których próbowano

\footnotetext{
56 Wunderink, Nieboer, Wiersma et al. (2013).

57 Moncrieff (2016b).

58 Seikkula, Alakare, Aaltonen et al. (2006); Dyga, Stupak (2014).

59 Calton, Ferriter, Huband et al. (2008); Stupak, Dobroczyński (2019).

${ }^{60}$ American Diabetes Association (2004); Rzewuska (2007).

61 Ho, Andreasen, Ziebell et al. (2011).

62 Jääskeläinen, Juola, Hirvonen et al. (2013).

63 Kirsch, Deacon, Huedo-Medina et al. (2008).

${ }^{64}$ Oronowicz-Jaśkowiak, Bąbel (2019).
} 
ocenić ich skuteczność poza badaniami klinicznymi, wykazały także, że „w prawdziwym świecie" skuteczność ta jest nawet niższa niż w przypadku placebo w badaniach klinicznych - co najprawdopodobniej spowodowane jest kryteriami doboru pacjentów do prób klinicznych ${ }^{65}$. Pojawiają się także hipotezy, że leczenie antydepresantami prowadzi do wystąpienia tolerancji i może zwiększać ryzyko nawrotów choroby w przyszłości ${ }^{66}$ i coraz głośniej mówi się o fizycznej zależności występującej u osób długoterminowo przyjmujących SSRI oraz znacznie częstszymi, dłuższymi i bardziej dotkliwymi, niż to się początkowo wydawało, objawami odstawienia: według nowszych badań zjawisko to może dotyczyć ponad połowy pacjentów próbujących odstawić leki, a w wypadku prawie połowy z nich wiąże się to z ciężkimi objawami odstawienia ${ }^{67}$. Jest to szczególnie problematyczne w świetle doniesień oceniających, że w prawie 1/4 przypadków nieleczonej depresji do remisji dochodzi spontanicznie w ciągu 3 miesięcy, a w ciągu roku - w ponad połowie ${ }^{68}$, a oddziaływania psychoterapeutyczne mają często podobną skuteczność69. Rodzi to także uzasadnione pytania, czy czas „dobierania leków” i oczekiwania na ich ",terapeutyczny efekt” lub długie oczekiwanie na efekt psychoterapii i następująca po wielu miesiącach poprawa nie jest w wielu wypadkach po prostu naturalną, niezależną od interwencji, remisją. Nie oznacza to, oczywiście, że ze stosowania leków powinno się zrezygnować, sugeruje jednak, że zalecenia związane z ich używaniem warto byłoby przemyśleć, biorąc także pod uwagę, że SSRI istotnie zwiększają ryzyko zachowań agresywnych i autoagresywnych - szczególnie u dzieci i nastolatków ${ }^{70}$, ale także u zdrowych osób ${ }^{71}$, co utrudnia złożenie tego efektu na podłoże chorobowe. Przegląd badań porównujący współczesne wyniki leczenia depresji z wynikami sprzed ery farmakoterapii wykazuje, że długoterminowe prognozy są obecnie gorsze niż kiedyś s2 $^{\text {. }}$

Aktualnie spore nadzieje wiąże się z zastosowaniem w terapii depresji ketaminy lub substancji działających w zbliżony do niej sposób na receptory glutaminergiczne. W zgodzie z biomedycznym rozumieniem zaburzeń depresyjnych próbuje się równocześnie wyeliminować lub zminimalizować objawy psychotyczne wywoływane przez tę substancję ${ }^{73}$, niektórzy autorzy wskazują jednak, że to właśnie doświadczenie odmiennych stanów świadomości może mieć terapeutyczny efekt i postulują stosowanie ketaminy jako środka wspomagającego psychoterapię ${ }^{74}$, podobnie jak ma to już miejsce, $\mathrm{z}$ dobrymi efektami, $\mathrm{w}$ terapii uzależnienia od alkoholu ${ }^{75} \mathrm{i} w$ badaniach $\mathrm{z}$ zastosowaniem 3,4-metylenodioksymetamfetaminy (MDMA) w terapii zespołu stresu pourazowego $(\mathrm{PTSD})^{76}$. Food and Drug Administration zatwierdziło enancjomer ketaminy - esketami-

${ }^{65}$ Kirsch, Huedo-Medina, Pigott el al. (2018).

${ }^{66}$ Fava (2011).

${ }^{67}$ Davies, Read (2018).

${ }^{68}$ Whiteford, Harris, McKeon et al. (2013).

${ }^{69}$ Kamenov, Twomey, Cabello et al. (2017).

70 Sharma, Guski, Freund et al. (2016).

${ }^{71}$ Bielefeldt, Danborg, Gotzsche (2016).

${ }^{72}$ Mulder, Frampton (2013).

${ }^{73}$ Abbasi (2017).

${ }^{74}$ Jansen (2004).

${ }^{75}$ Krupitsky, Grinenko (1997).

${ }^{76}$ Mithoefer, Wagner, Mithoefer et al. (2011); Mithoefer, Mithoefer, Feduccia et al. (2018). 
nę do stosowania na podstawie 4 prób klinicznych, w trzech krótkoterminowych próbach tylko jedna wykazała przewagę esketaminy nad placebo, czwarta próba wykazała dłuższy czas do nawrotu u stosujących preparat $\mathrm{w}$ połączeniu $\mathrm{z}$ innym antydepresantem, w porównaniu do tych, którzy przestali go przyjmować. Uzasadniło to nadanie esketaminie oficjalnego statusu przełomowej terapii ${ }^{77}$.

Również próby zastosowania innego rodzaju nowych terapii biologicznych przynoszą niezadowalające wyniki. Na przykład, w niedawno opublikowanym badaniu dotyczącym leczenia przy użyciu przezczaszkowej stymulacji magnetycznej weteranów wojennych z lekooporną depresją osiągnięto wyniki identyczne z zastosowaniem placebo (sham procedure) ${ }^{78}$. Co ciekawe, w obu grupach remisję osiągnęło prawie $40 \%$ uczestników badania, a placebo miało nawet niemal istotny statystycznie $(p=0,07)$ lepszy rezultat, jeśli chodzi o niwelowanie objawów PTSD. Wysokiego wskaźnika remisji lekoopornej depresji w grupie kontrolnej i eksperymentalnej nie można więc wytłumaczyć inaczej niż odwołując się do społecznego i kulturowego kontekstu samego uczestnictwa w badaniu oraz uwagi, którą poświęcono pacjentom lub faktowi, że czuli się dzięki temu potrzebni. Wskazuje to na niebagatelne znaczenie czynników psychologicznych i społecznych w zdrowieniu.

\section{Uwagi końcowe}

Model biomedyczny, jak wskazuje Moncrieff ${ }^{79}$ doskonale współgra z „neo-liberalnym” dyskursem i praktykami, szczególnie jeśli chodzi o akcentowanie w etiologii zaburzeń psychicznych czynników działających na poziomie jednostki (a więc np. genetycznych i biologicznych, w oderwaniu od społecznych), tym samym wyłącznie w jednostce umiejscawiając de facto przyczynę i źródło (żeby nie powiedzieć: „odpowiedzialność za") zaburzenia. Do podobnych wniosków dochodzą Cosgrove i Karter ${ }^{80}$. Tymczasem wiele badań pokazuje, że status materialny i społeczny ${ }^{81}$, przynależność do mniejszości etnicznej ${ }^{82}$, czy bycie ofiarą znęcania się w dzieciństwie ${ }^{83}$ mają związek z zapadalnością na poszczególne zaburzenia (a przynajmniej częstością ich diagnozowania!). Niedawno opublikowane dane z longitudinalnych badań pokazują np. związek problemów finansowych brytyjskich studentów z poziomem depresji oraz nadużywaniem alkoholu, wskazując na pierwotny charakter czynników ekonomicznych ${ }^{84}$, co jasno wskazuje, że uwarunkowań społecznych nie można ignorować. Jak mówi dr Eleanor Longden, znana aktywistka na rzecz praw osób uznanych za chore psychicznie, sama z diagnozą schizofrenii, „Kluczowe pytanie w kwestiach zdrowia psychicznego powinno brzmieć: co ci się stało, a nie: co z tobą nie tak?" 85 .

\footnotetext{
77 Food and Drug Administration (2019).

78 Yesavage, Fairchild, Mi et al. (2018).

79 Moncrieff (2008b).

80 Cosgrove, Karter (2018).

81 Wicks, Hjern, Daman (2010).

82 Veling, Susser, van Os et al. (2008).

83 Varese, Smeets, Drukker et al. (2012).

${ }^{84}$ Richardson, Elliott, Roberts et al. (2017).

${ }^{85}$ Longden (2013).
} 
Pojawiające się współcześnie propozycje zmian systemowych i nowych koncepcji praktyk terapeutycznych ich przeciwnicy najchętniej sklasyfikowaliby jako „nie-medyczne" lub wręcz ",anty-naukowe”, ale nie byłoby to do końca uczciwe postawienie sprawy, bowiem niektóre z nich nie negują wcale dorobku modelu biomedycznego, a jedynie starają się go przekształcić i dopełnić, a jeden z najbardziej rozległych i dopracowanych projektów tego rodzaju (postpsychiatria) wywodzi się z brytyjskiego środowiska psychiatrycznego ${ }^{86}$. Ponadto, sam zarzut dotyczący niemedycznego charakteru interwencji jest de facto zarzutem stricte ideologicznym - tym bardziej, jeśli niemedyczne interwencje mają naukowo potwierdzoną skuteczność. Z całą pewnością jednak są to koncepcje kładące nacisk na kulturowy i społeczny kontekst zaburzeń psychicznych z jednej strony, a z drugiej podkreślające idiograficzny ich charakter, akcentujące wagę podejścia fenomenologicznego i hermeneutycznego.

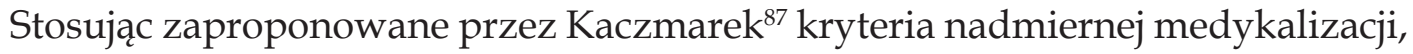
szczególnie w świetle przytoczonych tutaj wątpliwości dotyczących skuteczności i szkodliwości leczenia farmakologicznego przy pomocy neuroleptyków i antydepresantów, można by także dojść do wniosku, że właśnie o nadmiernej medykalizacji możemy w dziedzinie zdrowia psychicznego mówić. Medycyna nie dostarcza najbardziej adekwatnych narzędzi do wyjaśnienia, a tym bardziej zrozumienia, cierpienia psychicznego. Z objawami mamy do czynienia na poziomie zachowania, a nie na poziomie biologicznym, i wyłącznie na podstawie zachowania diagnozy psychiatryczne są stawiane wskaźniki biologiczne służą co najwyżej wykluczeniu chorób somatycznych, które mogą powodować podobne objawy. Alternatywne wyjaśnienia i oparte na nich terapie mają podobną lub wyższą skuteczność, co farmakoterapia, bez związanych z farmakoterapią poważnych skutków ubocznych.

Oczywiście, istnieją także publikacje starające się w zgoła odmienny sposób przedstawiać stan rzeczy. Celem niniejszego szkicu było jednak przywołanie tych badań i argumentów, które dominującą narrację o ogromnym postępie w biologicznym wyjaśnianiu i leczeniu zaburzeń psychicznych jeśli nie podważają, to przynajmniej komplikują. Argumenty te bowiem, z różnych powodów, są w dyskursie naukowym i publicznym marginalizowane, a w Polsce wręcz nieobecne.

Na koniec, warto jeszcze raz przywołać słowa Insela ${ }^{88}$, który podsumowując 13 lat pracy dla NIMH, stwierdził w 2017 r. że: „[...] co prawda, myślę, że udało mi się opublikować sporo fajnych badań zrobionych przez fajnych naukowców za dość duże pieniądze - chyba z 20 miliardów dolarów - nie wydaje mi się, żeby udało mi się wpłynąć w jakikolwiek sposób na zmniejszenie ilości samobójstw, hospitalizacji i poprawę stanu zdrowia dziesiątek milionów osób z chorobami psychicznymi". Jest to więc, być może, dobry moment, aby poważnie zastanowić się nad reformą zarówno metodologii badań psychiatrycznych, jak i konceptualizacją problemów badawczych i diagnoz psychiatrycznych, ale przede wszystkim nad zwiększeniem finansowania modeli prawdziwie środowiskowej i społecznej opieki psychiatrycznej o udowodnionej już skuteczności, i prac badawczych ujmujących problemy zaburzeń psychicznych całościowo, z uwzględ-

86 Bracken, Thomas (2001); Stupak, Dyga (2018).

87 Kaczmarek (2018).

88 Rogers (2017). 
nieniem czynników psychologicznych oraz kontekstów społecznych i kulturowych, także tych prowadzonych w paradygmacie jakościowym. Celem psychiatrii jako nauki nie powinno być przecież jedynie publikowanie „fajnych” badań, szczególnie jeśli okazuje się, że niewiele z nich praktycznie wynika, lecz przede wszystkim poszukiwane lepszych metod pomocy pacjentom, nawet jeśli miałoby się to wiązać z odejściem od modelu biomedycznego, przynajmniej w jego obecnym kształcie.

\section{Bibliografia}

Abbasi J. (2017), Ketamine Minus the Trip: New Hope for Treatment-Resistant Depression, „JAMA" 318 (20): 1964-1966.

Ahn R., Woodbridge A., Abraham A. et al. (2017), Financial Ties of Principal Investigators and Randomized Controlled Trial Outcomes: Cross Sectional Study, „BMJ” 356: i6770.

American Diabetes Association (2004), Consensus Development Conference on Antipsychotic Drugs and Obesity and Diabetes, „Diabetes Care” 27 (2): 596-601.

American Psychiatric Association (1994), Diagnostic and Statistical Manual of Mental Disorders. $4^{\text {th }}$ ed., "APA", Washington, DC.

Amsterdam J.D., McHenry L.B., Jureidini J.N. (2017), Zjawisko korupcji w badaniach psychiatrycznych, „Psychiatria Polska” 51 (6): 993-1008.

Bentall R.P. (2003), Madness Explained: Psychosis and Human Nature, Penguin, London.

Bernstein F. (1970), A Ten-Year History of the Early Clinical Drug Evaluation Unit (ECDEU) Program, „Psychopharmacol Bulletin” 6: 1-21.

Bielefeldt A.Ø., Danborg P.B., Gøtzsche P.C. (2016), Precursors to Suicidality and Violence on Antidepressants: Systematic Review of Trials in Adult Healthy Volunteers, "JRSM" 109 (10): 381-392.

Blashfield R.K., Keeley J.W., Flanagan E.H. et al. (2014), The Cycle of Classification: DSM-I Through DSM-5, „Annual Review of Clinical Psychology” 10 (1): 25-51.

Bond C.H. (1914), The Position of Psychiatry and the Role of the General Hospitals in Its Improvement, "The Lancet” 184 (4755): 935-940.

Bracken P., Thomas P. (2001), Postpsychiatry: A New Direction for Mental Health, „BMJ” 322 (7288): 724-727.

Calton T., Ferriter M., Huband N. et al. (2008), A Systematic Review of the Soteria Paradigm for the Treatment of People Diagnosed with Schizophrenia, "Schizophrenia Bulletin” 34 (1): 181-192.

Cosgrove L., Karter J.M. (2018), The Poison in the Cure: Neoliberalism and Contemporary Movements in Mental Health, "Theory \& Psychology" 28 (5): 669-683.

Cowen P.J., Browning M. (2015), What Has Serotonin to Do with Depression?, „World Psychiatry" 14 (2): 158-160.

Davies J. (2017), How Voting and Consensus Created the Diagnostic and Statistical Manual of Mental Disorders (DSM-III), „Anthropology \& Medicine” 24 (1): 32-46.

Davies J., Read J. (2018), A Systematic Review into the Incidence, Severity and Duration of Antidepressant Withdrawal Effects: Are Guidelines Evidence-Based?, "Addictive Behaviors” 97 (Oct 2019): 111-121.

de Barbaro B. (2014), Dylemat psychiatrii: „zły czy szalony”, „Psychiatra” 5 (7): 14-15.

Deacon B.J. (2013), The Biomedical Model of Mental Disorder: A Critical Analysis of Its Validity, Utility, and Effects on Psychotherapy Research, "Clinical Psychology Review" 33: 846-861. 
Dell'Osso L., Pini S. (2012), What Did We Learn from Research on Comorbidity in Psychiatry? Advantages and Limitations in the Forthcoming DSM-V Era, "Clinical Practice and Epidemiology in Mental Health" 8: 180-184.

Dub L.A., Lurie L.A. (1939), Use of Benzedrine in the Depressed Phase of the Psychotic State ,"Ohio State Medical Journal" 35: 39-45.

Dyga K., Stupak R. (2014), Obraz rehabilitacji psychiatrycznej w Polsce. Opis, porównania i ocena, [w:] Przepis na rehabilitację. Metodologie oraz metody $w$ badaniach i transdyscyplinarnej praktyce rehabilitacyjnej, W. Otrębski, G. Wiącek (red.), Wydawnictwo KUL, Lublin.

Eichenwald K., Kolata G. (1999), A Doctor's Drug Studies Turn into Fraud, URL = https:/ / partners.nytimes.com/library/national/science/health/051799drug-trials-industry. html [dostęp 1.08.2016].

Ellenberger H.F. (1970), The Discovery of the Unconscious: The History and Evolution of Dynamic Psychiatry, Basic Books, New York, NY.

Fava G.A., Offidani E. (2011), The Mechanisms of Tolerance in Antidepressant Action, „Progress in Neuro-Psychopharmacology \& Biological Psychiatry” 35 (7): 1593-1602.

U.S. Food and Drug Administration (2019), FDA Approves New Nasal Spray Medication for Treatment-Resistant Depression; Available Only at a Certified Doctor's Office or Clinic, URL = https://www.fda.gov/NewsEvents/Newsroom/PressAnnouncements/ ucm632761.htm [dostęp 23.03.2019].

Frances A.J. (2012), DSM-5 Field Trials Discredit APA, URL = https://www.psychologytoday.com/blog/dsm5-in-distress/201210/dsm-5-field-trials-discredit-apa [dostęp 23.02.2017].

Freemantle N., Anderson I.M., Young P. (2000), Predictive Value of Pharmacological Activity for the Relative Efficacy of Antidepressant Drugs: Meta-Regression Analysis, "The British Journal of Psychiatry" 177: 292-302.

Gøtzsche P. (2015), Deadly Psychiatry and Organised Denial, People's Press, Copenhagen.

Harrow M., Jobe T.H., Faull R.N. (2012), Do All Schizophrenia Patients Need Antipsychotic Treatment Continuously Throughout Their Life Time? A 20-Year Longitudinal Study, „Psychological Medicine” 42 (10): 2145-2155.

Harrow M., Jobe T.H., Faull R.N. et al. (2017), A 20-Year Multi-Followup Longitudinal Study Assessing Whether Antipsychotic Medications Contribute to Work Functioning in Schizophrenia, „Psychiatry Research” 256: 267-274.

Healy D. (2002), The Creation of Psychopharmacology, Harvard University Press, Cambridge, MA.

Hoffer A., Osmond H., Smythies J. (1954), Schizophrenia: A New Approach. II. Results of a Year's Research, „Journal of Mental Science” 100 (418): 29-45.

Ho B.-C., Andreasen N.C., Ziebell S. et al. (2011), Long-Term Antipsychotic Treatment and Brain Volumes: A Longitudinal Study of First-Episode Schizophrenia, "Archives of General Psychiatry" 68 (2): 128-137.

Hollister L. (1998), From Hypertension to Psychopharmacology: A Serendipitous Career, [w:] The Psychopharmacologists, t. 2, D. Healy (red.), Chapman \& Hall, London: 215-236.

Huston P., Moher D. (1996), Redundancy, Disaggregation, and the Integrity of Medical Research, „Lancet” 347: 1024-1026.

Insel T.R. (2006), Mental Illness and Brain Disease: Dispelling Myths and Promoting Recovery Through Awareness and Treatment. Subcommittee on Health of the Committee on Energy and Commerce, United States House of Representatives, URL = https:/ /www.gpo.gov/fdsys/pkg/CHRG-109hhrg30414/html/CHRG-109hhrg30414.htm [dostęp 10.06.2018]. 
Insel T.R. (2006b), NIMH's Dr. Thomas Insel: Group Advocacy, More Data, Will Improve Eating Disorders Research Funding, „Eating Disorders Review” 18: 5-6.

Insel T.R. (2010), Faulty circuits, „Scientific American” 302: 44-51.

Insel T.R. (2013), Transforming Diagnosis, URL = https://www.nimh.nih.gov/about/directors/thomasinsel/blog/2013/transforming-diagnosis.shtml [dostęp 26.01.2017].

Jääskeläinen E., Juola P., Hirvonen N. et al. (2013), A Systematic Review and Meta-Analysis of Recovery in Schizophrenia, „Schizophrenia Bulletin” 39 (6): 1296-1306.

Jansen K.L.R. (2004), Ketamine: Dreams and Realities, Multidisciplinary Association for Psychedelic Studies, Sarasota, FL.

Kaczmarek E. (2018), How to Distinguish Medicalization from Over-Medicalization?, „Medicine, Health Care and Philosophy" 22 (1): 119-128

Kamenov K., Twomey C., Cabello M. et al. (2017), The Efficacy of Psychotherapy, Pharmacotherapy and Their Combination on Functioning and Quality of Life in Depression: A Meta-Analysis, „Psychological Medicine” 47 (3): 414-425.

Kamens S.R., Robbins B.D., Flanagan E.H. (2017), Introduction to the Special Issues on Diagnostic Alternatives, "Journal of Humanistic Psychology" 57 (6): 567-572.

Kinderman P. (2014), A Prescription for Psychiatry, Palgrave Macmillan, Basingstoke, Hampshire.

Kirkpatrick B., Buchanan R.W., Ross D.E. et al. (2001), A Separate Disease Within the Syndrome of Schizophrenia, "Archives of General Psychiatry” 58 (2): 165-171.

Kirsch I., Deacon B.J., Huedo-Medina T.B. et al. (2008), Initial Severity and Antidepressant Benefits: A Meta-Analysis of Data Submitted to the Food and Drug Administration, „PLoS Med" 5 (2): e45.

Kirsch I., Huedo-Medina T.B., Pigott H.E. et al. (2018), Do Outcomes of Clinical Trials Resemble Those "Real World" Patients? A Reanalysis of the STAR*D Antidepressant Data Set, „Psychology of Consciousness: Theory, Research, and Practice” 5 (4): 339-345.

Krupitsky E.M., Grinenko A.Y. (1997), Ketamine Psychedelic Therapy (KPT): A Review of the Results of Ten Years of Research, "Journal of Psychoactive Drugs" 29 (2): 165-183.

Leo J. (2018), Memo to the Newest Generation of Gene Hunters: Read Jay Joseph, „Psychosis” 10 (1): 58-61.

Longden E. (2013), The Voices in My Head. TED Talk, URL = https://www.ted.com/talks/ eleanor_longden_the_voices_in_my_head?language=en [dostęp 11.08.2016].

Ludwig A.M. (1975), The Psychiatrist as Physician, "JAMA” 234 (6): 603-604.

Mithoefer M.C., Wagner M.T., Mithoefer A.T. et al. (2011), The Safety and Efficacy of \{+/-\}3,4-Methylenedioxymethamphetamine-Assisted Psychotherapy in Subjects with Chronic, Treatment-Resistant Posttraumatic Stress Disorder: The First Randomized Controlled Pilot Study, "Journal of Psychopharmacology" 25 (4): 439-452.

Mithoefer M.C., Mithoefer A.T., Feduccia A.A. et al. (2018), 3,4-Methylenedioxymethamphetamine (MDMA)-Assisted Psychotherapy for Post-Traumatic Stress Disorder in Military Veterans, Firefighters, and Police Officers: A Randomised, Double-Blind, Dose-Response, Phase 2 Clinical Trial, "Lancet Psychiatry” 5 (6): 486-497.

Moncrieff J. (2008), The Myth of the Chemical Cure, Palgrave Macmillan, Basingstoke, Hampshire.

Moncrieff J. (2008b), Neoliberalism and Biopsychiatry: A Marriage of Convenience, [w:] Liberatory Psychiatry: Philosophy, Politics, and Mental Health, C.I. Cohen, S. Timimi (red.), Cambridge University Press, New York, NY.

Moncrieff J., Kirsch I. (2015), Empirically Derived Criteria Cast Doubt on the Clinical Significance of Antidepressant-Placebo Differences, „Contemporary Clinical Trials” 43: 60-62. 
Moncrieff J. (2016), Misrepresenting Harms in Antidepressant Trials, „BMJ” 352: i217.

Moncrieff J. (2016b), New Research into Antipsychotic Discontinuation and Reduction: The RADAR programme, URL = https://joannamoncrieff.com/2016/03/02/new-research-into-antipsychotic-discontinuation-and-reduction-the-radar-programme/ [dostęp 10.06.2018].

Mulder R.T., Frampton C.M. (2013), Outcome of Mood Disorders Before Psychopharmacology: A Systematic Review, "Australian and New Zealand Journal of Psychiatry” 48 (3): 224-236.

Oronowicz-Jaśkowiak W., Bąbel P. (2019), Twenty Years After 'Listening to Prozac but Hearing Placebo'. Do We Hear Placebo Even Louder?, „Health Psychology Report” 7 (1): 1-8.

Pużyński S. (2014), Czy kryzys, „Psychiatra” 5 (7): 6-8.

Read J., Bentall R.P., Fosse R. (2009), Time to Abandon the Bio-Bio-Bio Model of Psychosis: Exploring the Epigenetic and Psychological Mechanisms by Which Adverse Life Events Lead to Psychotic Symptoms, „Epidemiology and Psychiatric Sciences” 18 (4): 299-310.

Rees W.L., King G.N. (1952), Cortisone in the Treatment of Schizophrenia, „The Journal of Mental Science" 98: 408-413.

Richardson T., Elliott P., Roberts R. et al. (2017), A Longitudinal Study of Financial Difficulties and Mental Health in a National Sample of British Undergraduate Students, "Community Mental Health Journal" 53 (3): 344-352.

Rogers A., Pilgrim D. (2001), Mental Health Policy in Britain, Palgrave Macmillan, Basingstoke, Hampshire.

Rogers D. (2017), Star Neuroscientist Tom Insel Leaves the Google-Spawned Verily for... A Startup?, URL = https://www.wired.com/2017/05/star-neuroscientist-tom-insel-leaves-google-spawned-verily-startup/ [dostęp 10.06.2018].

Rzewuska M. (2007), Zaburzenia metaboliczne zwiąane ze stosowaniem leków przeciwpsychotycznych u chorych na schizofrenię, „Psychiatria Polska” 41 (4): 457-472.

Sarchet P. (2011), Harvard Scientists Disciplined for Not Declaring Ties to Drug Companies, URL = http://blogs.nature.com/news/2011/07/harvard_scientists_disciplined.html [dostęp 30.10.2018].

Schizophrenia Working Group of the Psychiatric Genomics Consortium (2014), Biological Insights from 108 Schizophrenia-Associated Genetic Loci, „Nature” 511 (7510): 421-427.

Scull A. (1994), Somatic Treatments and the Historiography of Psychiatry, "Historiography of Psychiatry" 5: 1-12.

Seikkula J., Alakare B., Aaltonen J. et al. (2006), 5 Years Experiences of First-Episode Non-Affective Psychosis in Open Dialogue Approach: Treatment Principles, Follow-Up Outcomes and Two Case Analyses, „Psychotherapy Research” 16: 214-228.

Sharma T., Guski L.S., Freund N. et al. (2016), Suicidality and Aggression During Antidepressant Treatment: Systematic Review and Meta-Analyses Based on Clinical Study Reports, „BMJ” 352: i65.

Shorter E. (2005), Historia psychiatrii. Od zakładu dla obłakanych po erę Prozacu, tłum. P. Turski, Wydawnictwa Szkolne i Pedagogiczne, Warszawa.

Smith R. (2005), Medical Journals Are an Extension of the Marketing Arm of Pharmaceutical Companies, „PLoS Med” 2 (5): e138.

Spielmans G.I., Parry P.I. (2010), From Evidence-Based Medicine to Marketing-Based Medicine: Evidence from Internal Industry Documents, „Journal of Bioethical Inquiry” 7 (1): 13-29.

Stupak R., Dobroczyński B. (2019), Projekt Soteria: zwiastun "trzeciej drogi" w psychiatrii?, „Psychiatria Polska” 53 (6): 1351-1364. 
Stupak R., Dyga K. (2018), Postpsychiatry and Postmodern Psychotherapy: Theoretical and Ethical Issues in Mental Health Care in a Polish Context, "Theory \& Psychology" 28 (6): 780-799.

Thacker P.D. (2018), Time to Act on Industry Influence Over Medicine and Lay Zombie Arguments to Rest, URL = https:/ / blogs.bmj.com/bmj/2018/10/05/paul-d-thacker-time-to-acton-industry-influence-over-medicine-and-lay-zombie-arguments-to-rest/ [dostęp 30.10.2018].

The Brainstorm Consortium (2018), Analysis of Shared Heritability in Common Disorders of the Brain, „Science” 360 (6395): eaap8757.

Varese F., Smeets F., Drukker M. et al. (2012), Childhood Adversities Increase the Risk of Psychosis: A Meta-Analysis of Patient-Control, Prospective and Cross-Sectional Cohort Studies, „Schizophrenia Bulletin” 38 (4): 661-671.

Veling W., Susser E., van Os J. et al. (2008), Ethnic Density of Neighborhoods and Incidence of Psychotic Disorders Among Immigrants, „The American Journal of Psychiatry” 165 (1): 66-73.

Waszkiewicz A.A., Nizio A.M. (2014), Rola psychologa klinicznego w szpitalu psychiatrycznym, „Psychiatria i Psychoterapia” 10 (1): 3-10.

Whitaker R. (2002), Mad in America: Bad Science, Bad Medicine, and the Enduring Mistreatment of the Mentally Ill, Perseus Publishing, Cambridge, MA.

Whitaker R. (2016), The Case Against Antipsychotics: A Review of Their Long-Term Effects, URL = http://www.madinamerica.com/wp-content/uploads/2016/07/The-CaseAgainst-Antipsychotics.pdf [dostęp 10.08.2016].

Whiteford H.A., Harris M.G., McKeon G. et al. (2013), Estimating Remission from Untreated Major Depression: A Systematic Review and Meta-Analysis, "Psychological Medicine" 43 (8): 1569-1585.

Wicks S., Hjern A., Dalman C. (2010), Social Risk or Genetic Liability for Psychosis? A Study of Children Born in Sweden and Reared by Adoptive Parents, "The American Journal of Psychiatry" 167 (10): 1240-1246.

Williams J.B., Gibbon M., First M.B. et al. (1992), The Structured Clinical Interview for DSMIII-R (SCID): II. Multisite Test-Retest Reliability, "Archives of General Psychiatry" 49 (8): 630-636.

Wolfers T., Doan N.T., Kaufmann T. et al. (2018), Mapping the Heterogeneous Phenotype of Schizophrenia and Bipolar Disorder Using Normative Models, "JAMA Psychiatry" 75 (11): 1146-1155.

Wunderink L., Nieboer R.M., Wiersma D. et al. (2013), Recovery in Remitted First-Episode Psychosis at 7 Years of Follow-Up of an Early Dose Reduction/Discontinuation or Maintenance Treatment Strategy: Long-Term Follow-Up of a 2-Year Randomized Clinical Trial, "JAMA Psychiatry" 70 (9): 913-920.

Yesavage J.A., Fairchild J.K., Mi Z. et al. (2018), Effect of Repetitive Transcranial Magnetic Stimulation on Treatment-Resistant Major Depression in US Veterans: A Randomized Clinical Trial, „JAMA Psychiatry" 75 (9): 884-893. 